\title{
Legal Analysis on The Role Of Indonesian Central Government In The Eradication Of Trafficking In Persons
}

\author{
Rotua Valentina \\ \{val77ina@yahoo.com\} \\ Universitas Jayabaya, Jakarta, Indonesia
}

\begin{abstract}
Trafficking in persons (TiPs) is an organized crime against humanity. Indonesia has shown strong commitments to eradicate TiPs. As part of legislations commitment, Indonesia's Anti-Trafficking Law Number 21 Year 2007 provides a comprehensive framework defining TiPs in line with the Protocol to Prevent, Suppress and Punish Trafficking in Persons, Especially Women and Children, Supplementing the United Nations Convention against Transnational Organized Crime, criminalizing the offence of TiPs; while formalizing State's obligations to protect victims. Indonesia has also ratified the Protocol as Law Number 14 Year 2009. In addition, in 2017, Indonesia has ratified the ASEAN Convention Against Trafficking in Persons, Especially Women and Children as Law Number 12 Year 2017. Despite the fact that in term of migrant workers, Indonesia has ratified the International Convention on the Protection of the Rights of All Migrant Workers and Members of Their Families as Law Number 6 Year 2012, and enacted Law Number 18 Year 2017 on the Protection of Indonesian Migrant Workers, a big majority of victims of TiPs are Indonesian women and children being trafficked through recruitment channels for migrant workers purposes, including as domestic workers and working in the fishery sector. Following the laws and local autonomy spirit in Indonesia, central government has an important role in eradicating TiPs. This paper examines the role of central government in the prevention of the TiPs, by examining the case of Indonesia and reviewing all existing laws and regulations, including relates with international and regional human rights instruments.
\end{abstract}

Keywords: Trafficking in persons; Transnational organized crime; Migrant workers; Legislation.

\section{Introduction}

The human trafficking business has become the second-largest source of illegal income in the world (Belser, 2005), divided by circumstances such as social conditions (Richard, 2000), economics, and politics (Commission on the Social Determinants of Health, 2008). This exploitation is driven by criminal groups using poverty and existing movements in society (Perry \& McEwing, 2013). The United Nations Office on Drugs and Crime (2012) estimates that $75 \%$ of victims of human trafficking are women and children. Women make up 55\% to $60 \%$ of all trafficking victims globally, followed by girls at 17\%. However, UNODC (2012) estimates for 2007-2010 reveal an increase in the total percentage of children from $20 \%$ to $27 \%$.

However, human trafficking is a worldwide phenomenon, and Southeast Asia is known as the largest centre (International Organization for Migration, 2000). Conservatively, it is estimated that 225,000 women and children are trafficked each year. In fact, about a third of 
human trafficking globally (Richard, 1999). That $60 \%$ of victims of human trafficking in Southeast Asia are directed to big cities, while $40 \%$ are trafficked to various locations around the world (Congressional Research Service, 2000). One of the main factors contributing to the high rate of human trafficking in Southeast Asia is "sex tourism." Traffickers are driven by "large tax-free benefits and the [sustainable] income of the same victims at very low risk (Congressional Research Service, 2000). The International Labour Organization conducted a 1998 survey of Southeast Asia and found that the sex industry in the region accounts for $2 \%$ to 14\% of Gross Domestic Product (Lim, 1998).

In Indonesia, cases of trafficking in persons are estimated from 74,616 to 1 million Indonesians per year (Secretariat of the Task Force for the Prevention and Handling of Trafficking in Persons, 2016). In the Criminal Code, many articles can be used to take action against traffickers, such as Article 297, Article 324, Article 328, Article 329, Article 378, Article 506. criminal act of people-trafficking. The problem of trafficking has now become a public problem that must be immediately addressed by both central and local governments, because without any action taken by the government in anticipating and handling cases of trafficking in persons, it is feared that the series of human trafficking cases will continue.

\section{Human Trafficking}

The definition of human trafficking is trafficking whose objects are human (especially women and children), with or without the consent of the person concerned, within a country or abroad, with the aim of becoming workers who are exploitative in nature, other than that generally they will be employed as prostitution workers and slavery under the guise of marriage (Wijers \& Lap-Chew, 1999). United Nations Office on Drugs and Crime (tanpa tahun) mendefinisikan human trafficking as "Human Trafficking is the recruitment, transportation, transfer, harbouring or receipt of people through force, fraud or deception, with the aim of exploiting them for profit.

Men, women and children of all ages and from all backgrounds can become victims of this crime, which occurs in every region of the world. The traffickers often use violence or fraudulent employment agencies and fake promises of education and job opportunities to trick and coerce their victims." According to Law No. 21 of 2007 concerning the Eradication of the Crime of Trafficking in Persons defines human trafficking as "The act of recruiting, transporting, harbouring, sending, transferring, or receiving someone with threats of violence, kidnapping, confinement, forgery, fraud, abuse of power or a position of vulnerability. , debt bondage or giving payments or benefits, so as to obtain the consent of the person who has control over the other person, whether carried out within a country or between countries, for the purpose of exploitation or causing people to be exploited."

\section{Research Methods}

The method used in this study is a normative legal research method. Thus, data collection techniques were carried out and sourced from secondary data such as legislation, legal theory, opinions of legal experts, as well as legal provisions relating to the discussion to be achieved in this research. The type of research used is a normative juridical research type, the approach used is a statutory approach, namely by reviewing legislation related to the central theme of the research. In addition, other approaches are used to clarify the scientific analysis needed in normative research. 


\section{Results and Discussion}

\section{Legal Arrangements Regarding the Role of the Central Government in Combating the Crime of Trafficking in Persons}

Law Number 21 of 2007 concerning Eradication of the Crime of Trafficking in Persons is the government's effort to anticipate the rampant trafficking in persons. The existence of this law is based on the following thoughts: (1) trafficking in persons is an act that is contrary to human dignity and human rights; (2) that trafficking in persons has spread in the form of an organized network so that it becomes a threat to the community, nation, and state as well as abroad. and (3) that the desire to prevent and combat the criminal act of trafficking in persons is based on noble values, national and international commitments to carry out early prevention efforts, take action against perpetrators, protect victims, and increase cooperation.

Before the law was legalized, it began with government policies related to trafficking in women and children, as enshrined in the Criminal Code and Law Number 39 of 1999 concerning Human Rights. On December 30, 2002, Presidential Decree No. 88/2002 concerning the National Action Plan for the Elimination of Trafficking in Women and Children, which is guaranteed to be implemented, established a National Task Force. The basis for the establishment of the Law on the Eradication of the Crime of Trafficking in Persons is the 1945 Constitution Article 20, Article 21, and Article 28B paragraph (2), Convention on the Elimination of All Forms of Discrimination Against Women (CEDAW) which Indonesia has ratified through Law -Law Number 7 of 1984, and Law Number 23 of 2002 concerning Child Protection.

From several definitions of trafficking in persons regulated in various legal instruments, it provides an overview of trafficking in persons as a form of a criminal act that greatly violates human rights, so it is important to take various actions that can reduce and protect victims of trafficking in persons. In addition, the formulation of the PTPPO Law is also based on the 2000 Palermo Convention and the United Nations Protocol for the prevention, eradication, and prosecution of traffickers in human beings, especially women and children. In Indonesia, the regulation regarding trafficking in persons is contained in the 1945 Constitution Articles 28A, 28G, 28I (1), Law Number 39 of 1999 concerning Human Rights Article 20, and explicitly in Law Number 21 of 2007 concerning the Eradication of Criminal Acts. Trafficking in Persons.

The Role of the Central Government in Combating the Crime of Trafficking in Persons

The problem of trafficking has now become a public problem that must be immediately addressed by both central and local governments because without any action taken by the government in anticipating and dealing with cases of trafficking in persons, it is feared that the series of human trafficking cases will continue. The theory of criminal policy as put forward by Hoefnagles that criminal policy is a rational effort from the government and society in carrying out countermeasures is carried out through (Arief, 2016):

a. Criminal policy is the science of responses

b. Criminal policy is the science of crime prevention

c. Criminal Policy is a policy of designating human behaviour as crime

d. Criminal Policy is a rational total of the responses to crime

The synergy of the prevention theory above is linked to Law Number 21 of 2007 concerning the Eradication of the Crime of Trafficking in Persons, that all disciplines are part of criminal policy as an effort to prevent crime. Countermeasures that are part of social policy are essentially an integral part of community protection efforts that can be pursued in two ways, namely: 
1. The penal route, namely by applying criminal law

2. Non-penal path, namely by:

a. Prevention without crime, including the application of administrative sanctions and civil sanctions.

b. Influencing public views on crime and coaching through the mass media.

In the Elucidation of Law Number 21 of 2007 concerning the Eradication of the Crime of Trafficking in Persons, paragraph 7 that "Prevention and handling of criminal acts of trafficking in persons is the responsibility of the Government, Regional Governments, communities and families. To realize comprehensive and integrated steps in the implementation of prevention and treatment, it is necessary to form a task force." In carrying out prevention, it is necessary to cooperate with the government, task force units, the community and international cooperation, which is expected to reduce or prevent the occurrence of trafficking in persons. In the Task Force Report (2016) there are several steps taken to prevent the Crime of Trafficking in Persons, namely:

1. Book II of the 2015-2019 National Medium Term Development Plan (RPJMN) contains a commitment to increase protection for women from various acts of violence, including the crime of trafficking in persons.

2. Developing policies, guidelines and mechanisms for prevention.

3. Conducting community education (women's economic enterprises), equality education, course and institutional education, development of prevention models in 10 provinces of sending areas (West Java, Central Java, East Java, West Nusa Tenggara, East Nusa Tenggara, West Kalimantan, East Kalimantan, North Sulawesi, North Sumatra, and Riau Islands).

4. Preparation of regional action plans that integrate the issue of TIP in the local content of formal and non-formal schools in 20 districts/cities.

5. Implementing 12-year compulsory education.

6. Establishing an effective monitoring system on the performance of Private Indonesian Migrant Worker Delivery Companies.

7. Tightening monitoring of immigration flows in vulnerable areas.

8. Developing a service system for handling Indonesian Migrant Workers.

9. Establishment of a non-procedural TKI prevention task force by the Ministry of Manpower, at 21 embarkation locations.

10. Increasing security of travel documents and handling at the immigration department.

The crime of trafficking in persons is a crime that does not only occur within one country's territory but also between countries. Therefore, it is necessary to develop international cooperation in the form of mutual assistance agreements in criminal matters and/or other technical cooperation in accordance with the provisions of laws and regulations. The Crime of Trafficking in Persons is expected to be a repressive effort that gives a deterrent effect to the perpetrators. Of course, in applying these rules, there needs to be good cooperation between the central government and local governments.

Currently, at the regional level, several regional governments at the provincial to regency/municipal levels are trying to establish a legal institution in the form of a regional regulation (Perda) as a further elaboration of Law Number 21 of 2007 concerning the Eradication of the Crime of Trafficking in Persons. This shows that the Indonesian government wants to eradicate human trafficking, especially in Indonesia. The laws and regulations governing the criminal act of trafficking in persons are an attempt by the government to realize the protection of human dignity in accordance with the principle of protecting human rights. Violation of the criminal act of trafficking in persons as part of human rights law shows that 
there is still differentiation in society. Although the regulation on the criminal act of trafficking in persons has been enacted, it is still not running effectively, because there are still many violations.

\section{Conclusion}

Law Number 21 of 2007 concerning Eradication of the Crime of Trafficking in Persons is the government's effort to anticipate the rampant trafficking in persons. So that it has a goal to protect, maintain, and improve human dignity by trying to protect from the criminal act of trafficking in persons. Efforts to eradicate criminal acts of trafficking in persons are carried out employing eradicating criminal acts of trafficking in persons in a pre-emptive, preventive and repressive manner. By coordinating law enforcement officers, community participation, and strengthening roles in the field of legislation related to trafficking in persons.

\section{References}

[1] Wijers, M., \& Lap-Chew, L. (1999). Trafficking in Women: Forced Labour and Slavery-Like Practices in Marriage, Domestic Labour and Prostitution. Foundation Against Trafficking in Women (stv).

[2] Perry, K. M., \& McEwing, L. (2013). How do social determinants affect human trafficking in Southeast Asia, and what can we do about it? A systematic review. Health \& Hum. Rts., 15, 138.

[3] Sekretariat Gugus Tugas Pencegahan dan Penanganan Tindak pidana Perdagangan Orang. (2016). Laporan Pencegahan dan Penanganan Tindak Pidana Perdagangan Orang. Kementerian Pemberdayaan Perempuan dan Perlindungan Anak Republik Indonesia.

[4] Belser, P. (2005). Forced labour and human trafficking: Estimating the profits. Geneva: International Labour Organization.

[5] Commission on the Social Determinants of Health (CSDH). (2008). Closing the gap in a generation: Health equity through action on the social determinants of health, final report of the Commission on Social Determinants of Health. Geneva: WHO.

[6] Richard, A. O. (2000). Center for the Study of Intelligence, International trafficking in women to the United States: A contemporary manifestation of slavery and organized crime. Washington, DC: Center for the Study of Intelligence.

[7] International Organization for Migration. (2000). Combating trafficking in South-East Asia: A review of policy and programme responses. Geneva: IOM.

[8] Congressional Research Service. (2000). Trafficking in women and children: The U.S. and international response. Washington, DC: CRS.

[9] Barda Nawawi Arief, S. H. (2016). Bunga rampai kebijakan hukum pidana. Jakarta: Prenada Media.

[10] Republik Indonesia. Undang-undang (UU) No. 21 Tahun 2007 tentang Pemberantasan Tindak Pidana Perdagangan Orang. LN.2007/NO.58, TLN NO.4720. 